\title{
Hubungan Kemandirian Belajar dengan Hasil Belajar Matematika Siswa Kelas V SDN Se-Kecamatan Grabag Tahun Ajaran 2019/2020
}

\author{
Meirika Tri Asworowati ${ }^{1}$, Joharman ${ }^{2}$, Ngatman $^{3}$ \\ 1,2,3Universitas Sebelas Maret \\ Meirika100598@gmail.com
}

\section{Article History}

accepted 01/02/2020

approved 01/03/2020

published 01/04/2020

\begin{abstract}
The study aimed to prove positive correlation between independence in learning and mathematics learning outcomes and to determine the contribution of independence in learning to mathematics learning outcomes for fifth grade students of public elementary schools in Grabag sub-district in academic year of 2019/2020. It was a quantitative research with correlation method. Sampling method was cluster random sampling with Statistical Product and Service Solution (SPSS) version 25. The data collection techniques were questionnaire to obtain independence in learning variable and test to obtain mathematics learning outcomes. Data analysis used pearson product moment correlation test with a significance level of 0.05 and used adjusted $R$ square. The results showed that the value of correlation between students' independence in learning and mathematics learning outcomes was 0.339 with $p$-value $=0,000$ (Sig. $0.000<0.05$ ). The value of adjusted $R$ square was $11,5 \%$. It concludes that there is positive and significant correlation between independence in learning to mathematics learning outcomes for fifth grade students of public elementary schools in Grabag sub-district.
\end{abstract}

Keywords: Independence In Learning, Mathematics Learning Outcomes

\begin{abstract}
Abstrak
Penelitian ini bertujuan untuk membuktikan adanya korelasi positif antara kemandirian belajar dengan hasil belajar matematika siswa kelas V SDN se-Kecamatan Grabag tahun ajaran 2019/2020 dan untuk mengetahui besar sumbangan kemandirian belajar terhadap hasil belajar matematika siswa kelas V SDN se-Kecamatan Grabag tahun ajaran 2019/2020. Penelitian ini merupakan penelitian kuantitatif dengan metode korelasi. Pengambilan sampel dilakukan dengan teknik cluster random sampling dengan bantuan aplikasi Statistical Product and Service Solutions (SPSS) versi 25. Jumlah sampel dalam penelitian ini yaitu 275 siswa di 14 SDN seKecamatan Grabag. Pengambilan data menggunakan angket untuk memperoleh data pada variabel kemandirian belajar dan tes untuk memperoleh hasil belajar matematika. Analisis data menggunakan uji korelasi pearson product moment dengan taraf signifikansi 0,05 dan menggunakan sumbangan efektif. Hasil penelitian menunjukkan bahwa nilai koefisien korelasi kemandirian belajar terhadap hasil belajar matematika sebesar 0,339 dengan nilai $p$-value $=$ 0,000 (sig < 0,05). Nilai sumbangan positif variabel kemandirian belajar terhadap hasil belajar matematika sebesar $11,5 \%$. Berdasarkan analisis dan pembahasan hasil penelitian dapat disimpulkan bahwa terdapat hubungan yang positif dan signifikan antara kemandirian belajar dan hasil belajar matematika siswa kelas V SDN se-Kecamatan Grabag
\end{abstract}

Kata kunci: Kemandirian Belajar, Hasil Belajar Matematika 


\section{PENDAHULUAN}

Pendidikan memegang peranan penting dalam mendukung pembangunan nasional melalui pembentukan kualitas sumber daya manusia yang unggul. Pendidikan merupakan kegiatan yang dilakukan secara sadar dan terencana untuk membentuk siswa yang memiliki kecakapan tertentu melalui proses belajar. Pada pendidikan formal erat kaitannya dengan hasil belajar. (Taurina, 2015) mengatakan "Learning outcomes are described as written statements of what a learner is expected to know, understand and/or be able to do at the end of a period of learning", yang berarti hasil belajar merupakan pernyataan tentang apa yang diharapkan dapat diketahui siswa pada akhir pembelajaran. (Iryani, 2014) menyatakan bahwa hasil belajar adalah perubahan tingkah laku baik segi pengetahuan, sikap, dan keterampilan dalam diri peserta didik akibat dari proses pembelajaran. Perubahan tersebut berupa peningkatan yang lebih baik dibandingkan sebelum proses pembelajaran. Matematika didefinisikan sebagai "studi dengan logika yang ketat dari topik seperti kuantitas, struktur, ruang, dan perubahan" (Permendikbud, 2014). (Suhendri, 2011) berpendapat bahwa matematika adalah ilmu tentang bilangan, bangun, hubungan antar konsep, dan logika dengan menggunakan lambang kehidupan sehari-hari untuk menyelesaikan masalahmasalah.

Berdasarkan uraian di atas, maka disimpulkan bahwa hasil belajar matematika adalah puncak dari pengalaman belajar yang berupa perubahan dalam bentuk kognitif, afektif, dan psikomotor dalam hal kemampuan tentang struktur, bilangan, bangun, hubungan antar konsep, ruang, dan logika yang berkesinambungan serta dapat diukur dan diamati.

Tinggi rendahnya hasil belajar siswa dipengaruhi oleh beberapa faktor. Faktorfaktor tersebut meliputi faktor dari dalam diri peserta didik itu sendiri dan faktor yang datang dari luar peserta didik. Faktor dari dalam diri peserta didik meliputi: kecerdasan, kemampuan berpikir kritis, motivasi, kesehatan, dan cara belajar serta kemandirian belajar. Sedangkan faktor yang berasal dari luar peserta didik meliputi: lingkungan keluarga, lingkungan sekolah, dan lingkungan masyarakat (Egok, 2016).

Keberhasilan belajar siswa dapat dilihat melalui hasil belajar siswa selama mengikuti proses pembelajaran. Salah satu faktor yang memengaruhi hasil belajar siswa adalah kemandirian belajar. (Tirtaraharja dan Sulo, 2018) menyatakan bahwa, "Kemandirian belajar diartikan sebagai aktivitas belajar yang prosesnya lebih didorong oleh kemauan sendiri, pilihan sendiri, dan disertai rasa tanggung jawab dari diri pembelajar". (Suhendri, 2011) juga berpendapat bahwa kemandirian belajar adalah suatu aktivitas belajar siswa tanpa bantuan orang lain baik teman maupun guru dalam mencapai tujuan belajar, yaitu menguasai pengetahuan dengan baik dengan kesadarannya sendiri dan dapat mengaplikasikannya dalam kehidupan sehari-hari.

Siswa yang memiliki kemandirian belajar tinggi, biasanya memiliki ciri-ciri, antara lain: mampu menyelesaikan masalah sendiri, percaya diri, memiliki inisiatif belajar tinggi, bertanggung jawab, memiliki keinginan untuk maju, dan mampu mengambil keputusan.

Berdasarkan pendapat di atas maka dapat disimpulkan pengertian kemandirian belajar yaitu suatu aktivitas belajar atas kemauan sendiri dalam mengerjakan dan memutuskan sesuatu yang ditandai dengan kemampuan dalam menyelesaikan masalah, percaya diri, memiliki inisiatif belajar yang tinggi, bertanggung jawab, memiliki keinginan untuk maju, dan mampu mengambil keputusan sehingga tujuan belajar dapat tercapai.

Menurut (Susanto, 2016), kemampuan pemahaman siswa terhadap materi pelajaran matematika masih rendah. Hal ini disebabkan karena anak usia sekolah dasar pada umumnya mengalami kesulitan dalam memahami matematika yang bersifat abstrak. Selain itu matematika tersusun secara hierarki, yaitu setiap pemberian materi pelajaran yang baru, siswa harus memahami bahkan mengingat materi 
sebelumnya (Heriyati, 2017). Alasan inilah yang menjadikan siswa merasa matematika adalah pelajaran yang sulit, kurang menarik dan membosankan. Siswa juga belum memahami hakekat dan kebermanfaatan matematika. Kemampuan pemahaman matematika yang rendah menandakan hasil belajar yang kurang maksimal. Dengan kemandirian belajar yang tinggi diharapkan dapat menghasilkan hasil belajar matematika yang maksimal.

Kemandirian belajar memiliki peranan yang penting dalam proses belajar siswa. Syahputra (2017) menyatakan bahwa dengan kemandirian siswa dapat belajar lebih baik, mampu memantau, mengevaluasi, dan mengatur belajarnya secara efektif. Hal tersebut dapat dikaitkan dengan simpulan Nagpal,dkk (2013) yang menyatakan bahwa "Urges students to take responsibility for their learning and not be "empty vessels"'. Maksud dari pendapat Nagpal, dkk yaitu kemandirian belajar mendesak siswa untuk bertanggung jawab atas pembelajaran dan membuat siswa tidak seperti bejana kosong.

Kemandirian belajar dan hasil belajar matematika memiliki hubungan. Rahmawati (2016) dalam penelitiannya menyakan bahwa terdapat hubungan yang positif antara kemandirian belajar dengan hasil belajar siswa SD Negeri Purwoyoso 06 Semarang, dengan $r$ tabel 0,560 lebih besar dari $r$ hitung 0,213 $(0,560>0,213)$ termasuk dalam tingkat hubungan sedang.

Hal tersebut berarti semakin tinggi kemandirian siswa, maka akan semakin tinggi pula hasil belajar matematika siswa. Begitu pun sebaliknya, semakin rendah kemandirian siswa, maka akan semakin rendah pula hasil belajar matematika siswa.

Berdasarkan penjelasan di atas, pemasalahan dalam penelitian ini adalah : (1) apakah kemandirian belajar siswa berkorelasi positif dengan hasil belajar matematika siswa kelas V SDN se-Kecamatan Grabag tahun ajaran 2019/2020?; (2) seberapa besar sumbangan kemandirian belajar terhadap hasil belajar matematika siswa kelas V SDN se-Kecamatan Grabag tahun ajaran 2019/2020?.

Berdasarkan permasalahan di atas maka tujuan dari penelitian ini yaitu : (1) untuk membuktikan adanya korelasi positif antara kemandirian belajar siswa dengan hasil belajar matematika siswa kelas V SDN se-Kecamatan Grabag tahun ajaran 2019/2020; (2) untuk mengetahui besarnya sumbangan kemandirian belajar terhadap hasil belajar matematika siswa kelas IV SDN se-Kecamatan Grabag tahun ajaran 2019/2020.

\section{METODE}

Desain penelitian yang digunakan yaitu penelitian kuantitatif dengan metode penelitian korelasi. Penelitian korelasi adalah penelitian yang melibatkan hubungan satu atau lebih variabel lain (Purwanto, 2012). Populasi penelitian ini yaitu siswa kelas V SDN se-Kecamatan Grabag sejumlah 701 siswa dengan sampel sebanyak 275 siswa di empatbelas SDN di Kecamatan Grabag. Teknik sampling yang digunakan yaitu cluster random sampling.

Ada beberapa teknik pengumpulan data dalam kegiatan penelitian, seperti: tes, kuesioner, interviu, dan dokumentasi (Arikunto, 2010). Teknik pengumpulan data pada penelitian ini menggunakan angket dan ujian (tes). Angket digunakan untuk mengumpulkan data penelitian pada variabel bebas yaitu kemandirian belajar, sedangkan ujian (tes) digunakan untuk mengumpulkan data penelitian pada variabel terikat yaitu hasil belajar matematika. Sebelum digunakan, angket dan tes diuji validitasnya terlebih dahulu. Pengujian dilakukan di 4 SDN di Kecamatan Grabag. Berdasarkan uji validitas angket uji coba kemandirian belajar, dari 63 butir angket yang diujikan terdapat 13 butir angket yang tidak valid dan 50 butir angket yang valid. Selanjutnya, uji validitas instrumen uji coba tes hasil belajar matematika siswa, dari 40 soal matematika yang diujikan, terdapat 10 soal yang tidak valid dan 30 soal yang valid. 
Sebelum dilakukan uji prasyarat analisis data, hasil data yang diperoleh dari angket kemandirian belajar masih berupa data ordinal, maka harus diubah menjadi data interval. Untuk mengubah data ordinal ke data interval, peneliti menggunakan bantuan MS. Excel add-ins for statistics. Setelah diubah ke data interval, maka hasil penelitian dapat dilakukan uji prasyarat. Uji prasyarat yang digunakan adalah uji normalitas menggunakan uji liliefors dan uji linieritas data. Uji hipotesis yang digunakan adalah uji korelasi sederhana dan sumbangan efektif. Uji korelasi sederhana digunakan untuk menguji ada atau tidaknya hubungan antara kemandirian belajar dengan hasil belajar. Uji sumbangan efektif digunakan untuk mencari besarnya sumbangan variabel kemandirian terhadap variabel hasil belajar.

\section{HASIL DAN PEMBAHASAN}

Hasil uji normalitas sebaran terhadap variabel kemandirian belajar menghasilkan nilai $p$-value sebesar 0,200 (sig > 0,05). Hasil uji berdasarkan kaidah menunjukkan variabel kemandirian belajar adalah normal. Hasil uji normalitas sebaran terhadap variabel hasil belajar matematika menghasilkan nilai $p$-value sebesar 0,087 (sig > 0,05). Hasil uji berdasarkan kaidah menunjukkan variabel hasil belajar matematika adalah normal.

Berdasarkan uji linieritas diperoleh nilai Sig. Deviation from Linearity untuk variabel kemandirian belajar dengan hasil belajar sebesar 0,537. Nilai Sig. Deviation from Linearity menunjukkan $>(0,05)$. Oleh karena itu data penelitian ini bersifat linier.

Berdasarkan hasil analisis dengan menggunakan uji korelasi pearson product moment, diketahui bahwa terdapat hubungan positif dan signifikan antara kemandirian belajar dan hasil belajar matematika dengan koefisien korelasi sebesar 0,339, dan Sig. (1-tailed) yaitu 0,000 ( $p$-value $<0,05)$. Sesuai dengan hasil dari uji korelasi tersebut, maka hipotesis yang menyatakan ada korelasi positif dan signifikan antara kemandirian belajar dengan hasil belajar matematika siswa kelas V SDN se-Kecamatan Grabag tahun ajaran 2019/2020 dapat diterima dan dalam kategori sedang. Berdasarkan hasil penelitian tersebut dapat disimpulkan bahwa semakin tinggi kemandirian belajar siswa, maka akan semakin tinggi pula hasil belajar matematika siswa. Begitupun sebaliknya, semakin rendah kemandirian belajar siswa, maka akan semakin rendah pula hasil belajar matematika siswa.

Diterimanya hipotesis ini sesuai dengan penelitian yang dilakukan oleh (Rahmawati, 2016) yang menyatakan bahwa terdapat hubungan positif antara kemandirian belajar dengan hasil belajar siswa SD Negeri Purwoyoso 06 Semarang, dengan $r$ tabel 0,560 lebih besar dari $r$ hitung $0,213(0,560>0,213)$ termasuk dalam tingkat hubungan sedang.

Hasil penelitian ini juga sejalan dengan penelitian yang dilakukan (Egok, 2016) yang menyatakan bahwa terdapat pengaruh positif dari kemandirian belajar siswa dengan hasil belajar matematika siswa kelas V di SDN Kota Bogor, dengan $r$ peroleh sebesar 0,405 dan termasuk dalam kategori sedang.

Selain itu hasil penelitian ini juga diperkuat oleh penelitian (Rosyidah, 2010) yang menyatakan bahwa kemandirian belajar memiliki hubungan positif dan signifikan dengan hasil belajar, sehingga mempengaruhi hasil belajar matematika, dimana siswa yang memiliki kemandirian belajar baik, akan memiliki tingkat hasil belajar matematika yang tinggi. Sebaliknya siswa yang memiliki kemandirian belajar yang kurang baik menyebabkan rendahnya hasil belajar matematika.

Sesuai hasil perhitungan sumbangan kemandirian belajar terhadap hasil belajar matematika, didapatkan hasil yang menyatakan bahwa kemandirian belajar dapat meningkatkan hasil belajar matematika sebesar $11,5 \%$ dan sisanya sebesar $88,5 \%$ dipengaruhi oleh faktor lain di luar penelitian ini. Hal tersebut sejalan dengan dengan penelitian Rosyidah (2010) yang menyatakan bahwa kemandirian belajar bukan satusatunya variabel atau faktor yang menyebabkan meningkatnya hasil belajar siswa, 
tetapi tedapat faktor-faktor lain yang mempengaruhi tinggi rendahnya hasil belajar siswa baik faktor internal maupun eksternal seperti motivasi, sarana dan prasarana, disiplin, lingkungan sekolah, lingkungan keluarga, lingkungan masyarakat, guru, dan lainnya.

Berdasarkan uraian di atas, dapat disimpulkan bahwa hasil penelitian ini telah sesuai dengan teori yang ada dan didukung pula dengan penelitian yang relevan, maka hasil penelitian ini adalah ada korelasi positif dan signifikan antara sikap kemandirian belajar dengan hasil belajar matematika siswa kelas V SDN seKecamatan Grabag tahun ajaran 2019/2020.

\section{SIMPULAN}

Berdasarkan hasil penelitian dan pembahasan, didapatkan kesimpulan bahwa terdapat hubungan yang positif dan signifikan antara kemandirian belajar dengan hasil belajar matematika siswa kelas V SDN se-Kecamatan Grabag tahun ajaran 2019/2020 dengan tingkat korelasi rendah yaitu 0,339. Artinya, semakin tinggi kemandirian belajar, maka akan semakin tinggi pula hasil belajar matematika siswa. Kemandirian belajar memberikan sumbangan positif terhadap hasil belajar matematika yaitu $11,5 \%$, sedangkan sisanya dipengaruhi faktor lain, seperti kesehatan, intelegensi, motivasi, perhatian dan minat, lingkungan keluarga, lingkungan sekolah, lingkungan masyarakat, sarana prasarana, dan bakat.

\section{DAFTAR PUSTAKA}

Arikunto, S. (2010). Prosedur Penelitian Suatu Pendekatan Praktik. Jakarta: Rineka Cipta.

Egok, A. S. (2016). Kemampuan Berpikir Kritis dan Kemandirian Belajar dengan Hasil Belajar Matematika. Jurnal Pendidikan Dasar Volume 7 Edisi 2: 186-199.

Heriyati. (2017). Pengaruh Minat dan Motivasi Belajar terhadap Prestasi Belajar Matematika Siswa SMP Negeri di Kecamatan Karawaci Tangerang. Jurnal Formatif, 7 (1), 22-32.

Iryani, I. (2014). Peningkatan Aktivitas dan Hasil Belajar Siswa Kelas V pada Pembelajaran Matematika Melalui Pendekatan Konstruktivisme di SD Negeri 04 Talamau. Artikel: 1-16.

Nagpal, dkk. (2013). Independent Learning and Student Development. International Journal of Social Science \& Interdisciplinary Research, 2 (2): 27-35.

Permendikbud. (2014). Peraturan Menteri Pendidikan dan Kebudayaan Republik Indonesia Nomor 57 Tahun 2014 Tentang Kurikulum 2013 Sekolah Dasar/Madrasah Ibtidaiyah.

Purwanto. (2012). Metode Penelitian Kuantitatif untuk Psikologi dan Pendidikan. Yogyakarta: Pustaka Pelajar.

Rahmawati, D. (2016). Hubungan Kemandirian Belajar dengan Hasil Belajar Siswa SD Negeri Purwoyoso 06 Semarang. Skripsi Tidak Dipublikasikan: Universitas Negeri Semarang.

Rosyidah. (2010). Hubungan Antara Kemandirian Belajar dengan Hasil Belajar Matematika pada Siswa MTsN Parung-Bogor. Skripsi Tidak Dipublikasikan. Universitas Islam Negeri.

Suhendri, H. (2011). Pengaruh Kecerdasan Matematis-Logis dan Kemandirian Belajar terhadap Hasil belajar Matematika. Jurnal Formatif 1(1): 29-39.

Susanto, A. (2016). Teori Belajar \& Pembelajaran di Sekolah Dasar. Jakarta: Prenadamedia Group.

Syahputra, D. (2017). Pengaruh Kemandirian Belajar dan Bimbingan Belajar Terhadap Kemampuan Memahami Jurnal, Penyesuaian pada Siswa SMA Melati Perbaungan. At-Tawasuh, Vol. II, No.2: 368-388. 
Volume 8 Nomor 1 Tahun 2020

Taurina, Z. (2015). Student's Motivation and Learning Outcomes: Significant Factor in Internal Study Quality Assurance System. International Journal for CrossDisciplinary Subjects in Education (IJCDSE), Special Issue Volume 5 Issue 4: 2526-2630.

Tirtarahardja, U. \& Sulo, L. (2018). Pengantar Pendidikan. Jakarta: Rineka Cipta. 